\title{
KAJIAN KONDISI STOK IKAN SELAR (Selar crumenophthalmus) DI PERAIRAN SERAM BARAT, MALUKU
}

\section{RESEARCH OF BIGEYE SCAD SUPPLY CONDITION (Selar Crumenophthalmus) IN WEST SERAM WATERS, MALUKU}

\author{
Alex S. W. Retraubun ${ }^{1 *}$, Winster Larwuy ${ }^{2}$, \& Ong T. S. Ongkers ${ }^{1}$ \\ ${ }^{1}$ Program Studi Manajemen Sumberdaya Kelautan dan Pulau Pulau Kecil, Program Pascasarjana, \\ Universitas Pattimura, Ambon, 97113, Indonesia \\ ${ }^{2}$ Program Studi Budidaya Ikan, Politeknik Kelautan Perikanan Maluku, Ambon, 97233, Indonesia \\ *E-mail: alexretraubun@yahoo.com
}

\begin{abstract}
Selar fish is a potential small pelagic fishery resource in Indonesian territorial waters and is located in Maluku Province, it specially in west seram waters. This research was carried out in the waters of West Seram, Maluku, from March 2018 to February 2019. The objective of research was to study the stock condition of bigeye scad, Selar crumenophthalmus, based on population dynamic from length frequency distribution. Fish samples were collected every month at fish landing from lift net fishers. Totally, there were 1890 individuals collected during the study, excepted June, composed of 925 males and 965 females with the length size ranging from $13.3 \mathrm{~cm}$ to $27.2 \mathrm{~cm}$ which was composed of 2 and 3 cohorts every month. Condition stock of bigeye scad based on yield per recruit analysis showed that the stock was still below the level of MSY (0.03 of 0.047), obtained from Lœ was $27.40 \mathrm{~cm}, K$ was $1.55 / y r, Z$ was 3.66/yr, M was 2.51/yr, F was 1.15/yr, E was 0.32/yr, Lc was $19.92 \mathrm{~cm}$ and to was -0.10 /yr. This shows that the higher Lc value of selar fish in west seram waters more selective and otherwise.
\end{abstract}

Keywords: bigeye scad, stock condition, West Seram waters

\begin{abstract}
ABSTRAK
Ikan selar adalah sumberdaya perikanan pelagis kecil yang potensial di perairan teritorial Indonesia dan berada di Provinsi Maluku, khususnya di perairan Seram Barat. Penelitian ini dilakukan di perairan Seram Barat, Maluku, dari bulan Maret 2018 sampai Februari 2019. Tujuan penelitian ini adalah mempelajari kondisi stok ikan Selar (Selar crumenopththalmus) didasarkan pada dinamika populasi dari distribusi frekuensi panjang. Contoh ikan dikoleksi tiap bulan di tempat pendaratan dari nelayan lift net. Total 1890 individu dikoleksi selama penelitian kecuali bulan Juni yang terdiri dari 925 jantan dan 965 betina dengan panjang berkisar dari 13,3 cm sampai 27,2 $\mathrm{cm}$ yang terdiri dari 2 dan 3 kelompok umur tiap bulan. Kondisi stok ikan selar didasarkan pada analisis hasil per penambahan individu baru menunjukkan bahwa stok masih di bawah tingkat MSY $(0,03$ dari 0,047$)$ yang diperoleh dari $\mathrm{L} \infty=27,40 \mathrm{~cm}, \mathrm{~K}=1,55 / \mathrm{yr}, \mathrm{Z}=3,66 /$ tahun, $\mathrm{M}=2,51 /$ tahun, $\mathrm{F}=1,15 /$ tahun, $\mathrm{E}=$ 0,32/tahun, Lc (panjang utk pertama kali tertangkap) $=19,92 \mathrm{~cm}$ and $\mathrm{t}_{0}=-0,10 / \mathrm{yr}$. Hal ini menunjukkan bahwa semakin tinggi nilai Lc ikan selar di Perairan Seram Barat akan semakin selektif dan sebaliknya.
\end{abstract}

Kata kunci: ikan selar, kondisi stok, perairan Seram Barat

\section{PENDAHULUAN}

Ikan selar atau dalam bahasa lokal disebut ikan kawalinya adalah sumberdaya perikanan pelagis kecil yang potensial di perairan teritorial Indonesia. Dimara et al.
(2015) menyatakan bahwa ikan selar/ikan malalugis putih adalah komoditi ekspor yang penting sejak tahun 1993, sehingga menjadikannya sebagai salah satu target tangkapan utama nelayan. Sesuai data produksi perikanan tangkap provinsi 
Maluku, ikan selar merupakan salah satu jenis sumberdaya produktif di perairan Maluku.

jenis $\begin{array}{ccc}\text { Penangkapan } & \text { ikan selar } & \text { terutama } \\ \text { selar } & \text { bentong } & \text { (Selar }\end{array}$ crumenophthalmus) yang selanjutnya disebut ikan selar telah dilakukan sejak lama di perairan Seram Barat oleh industri perikanan rakyat (artisanal) dengan intensitas yang cukup tinggi. Hasil observasi pada kegiatan pre-survey menunjukkan sebagai akibat pengelolaan yang bersifat common property menyebabkan penangkapan (fishing effort) dilakukan menggunakan berbagai jenis alat tangkap dengan selektivitas yang rendah dan tanpa adanya pemahaman mengenai musim tangkap. Kondisi perikanan seperti ini menjadi cukup berbahaya karena upaya penangkapan yang dilakukan tidak mengindahkan kaidah-kaidah keberlanjutan sumberdaya ikan sehingga kelestarian sumberdaya ikan menjadi terancam (Bunyamin et al., 2016).

Kondisi perikanan seperti di atas dapat memengaruhi status stok sumberdaya ikan terutama ikan selar. Kartini et al. (2017) menyatakan dampak yang akan terjadi apabila kegiatan penangkapan terus dilakukan adalah terjadinya perubahan status stok sumberdaya ikan. Melihat kondisi dan konsekuensi yang berpotensi terjadi, maka diperlukan pendekatan yang dapat digunakan untuk mengevaluasi perikanan ikan selar di perairan Seram Barat yakni melalui pengkajian stok.

Penelitian ini dilakukan untuk mengkaji kondisi stok ikan selar berbasis pada informasi dinamika populasi, yang menurut Octoriani et al. (2015), adalah hal yang sangat penting bagi pengelolaan yang efektif untuk memperoleh manfaat yang maksimum dari suatu sumberdaya ikan. Hasil penelitian ini diharapkan dapat menjadi input untuk mendasari pengelolaan sumberdaya ikan selar yang tepat dan berkelanjutan.

\section{METODE PENELITIAN}

\subsection{Waktu dan Lokasi Penelitian}

Penelitian dilakukan di perairan Seram Barat, Kecamatan Seram Barat, Kabupaten Seram Bagian Barat, Maluku (Gambar 1). Penelitian dilakukan dari bulan Maret 2018 hingga bulan Februari 2019, kecuali bulan Juni yang terjadi kekosongan data sebagai pengaruh musim timur yang menyebabkan nelayan tidak melaut. Lokasi sampling berada di perairan Pelita Jaya sebagai salah satu sentra penangkapan ikan selar di Kecamatan Seram Barat.

\subsection{Pengambilan Data}

Pengambilan data dilakukan secara time series, dimana data dikoleksi sekali dalam sebulan selama 11 bulan yang dipertimbangkan dapat menerangkan perubahan struktur ukuran dalam populasi. Penelitian serupa juga dilakukan Adeeb et al. (2014) selama lima bulan di perairan Bangaa Faru Maldives, Saranga et al. (2018) selama enam bulan di perairan sekitar Bitung, dan Khatami et al. (2019) selama enam bulan di perairan utara Jawa.

Sampel yang digunakan merupakan seluruh (100\%) hasil tangkapan/upaya nelayan bagan perahu (lift net), yang meliputi data ukuran total length (sesuai petunjuk Gonzales et al. (1997). Identifikasi jenis ikan selar dilakukan dengan bantuan buku identifikasi spesies menurut FAO (1983), dan Love et al. (2016).

Penelitian ini juga membutuhkan data suhu rata-rata perairan yang diperoleh dari data digital hasil pembacaan satelit MODISTerra pada lokasi cuplik perairan Seram Barat.

\subsection{Analisis Data}

Analisis kondisi stok ikan selar dilakukan berbasis aspek dinamika populasi, meliputi rata-rata panjang pertama kali tertangkap, parameter pertumbuhan, 


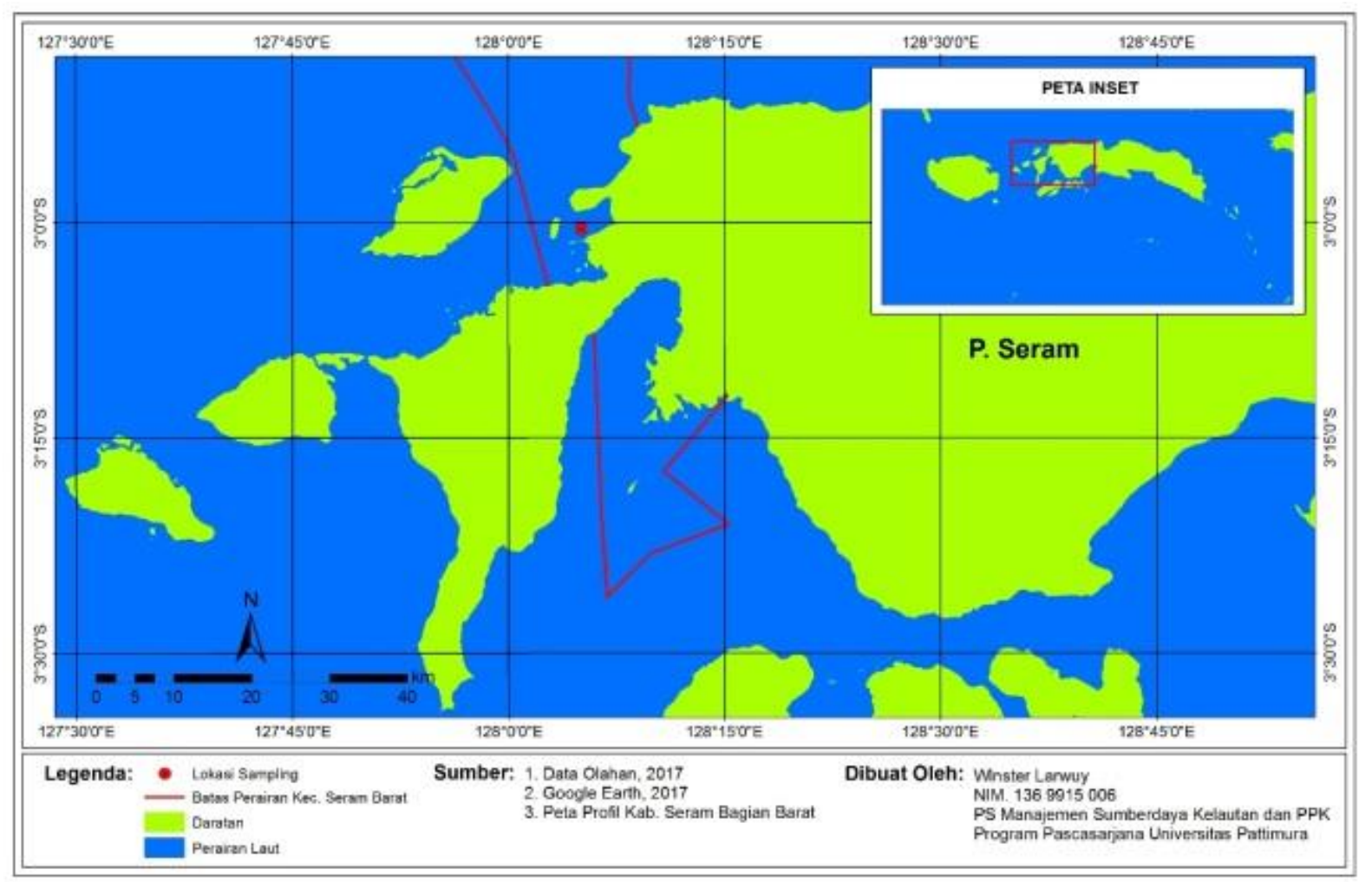

Gambar 1. Peta Lokasi Penelitian Seram Bagian Barat.

mortalitas dan laju eksploitasi. Analisis distribusi kelompok ukuran ikan selar menggunakan metode Bhattacharya (1967) dengan persamaan:

$\mathrm{FC}=\left(\frac{\mathrm{ndL}}{\mathrm{S} \sqrt{2 \pi}}\right) \mathrm{e}^{-\frac{(\mathrm{x}-\overline{\mathrm{x}})^{2}}{2 \mathrm{~S}^{2}}}$

Keterangan: $F c$ adalah frekuensi teoritis; $n$ adalah Jumlah individu; $d L$ adalah interval kelas; $\pi$ adalah kostanta $(3,14) ; x$ adalah panjang individu $(\mathrm{cm}) ; \bar{x}$ adalah panjang rata-rata individu $(\mathrm{cm}) ; S$ adalah standar deviasi.

Pendugaan rata-rata panjang pertama kali tertangkap dilakukan menggunakan kurva tangkapan dengan persamaan sebagai berikut (Sparre \& Venema, 1999):

$\mathrm{L}=\mathrm{L}_{50 \%}=\mathrm{Lc}=\frac{\mathrm{S} 1}{\mathrm{~S} 2}$

Keterangan: $L c$ adalah ukuran rata-rata pertama kali tertangkap (cm); $S_{1}$ adalah a (intercept); $S_{2}$ adalah b (slope); $S 1$ adalah konstanta pada rumus kurva; $S 2$ adalah tangkapan, dimana dimana sumbu $x$ adalah panjang individu $(\mathrm{cm})$ dan $y$ adalah frekuensi kumulatif/probabilitas tangkapan (\%).

Pendugaan parameter perumbuhan ikan selar dilakukan menggunakan persamaan pertumbuhan Von Bertalanffy, yang dapat ditulis sebagai berikut (Sparre \&Venema, 1999):

$L_{t}=L \infty\left(1-e^{-K(t-t 0)}\right)$

Keterangan: $L t$ adalah Panjang individu pada saat umur $\mathrm{t}(\mathrm{cm}) ; L \infty$ adalah Panjang asimtotik (invinity) $(\mathrm{cm}) ; K$ adalah Koefisien pertumbuhan $\left(\mathrm{yr}^{-1}\right)$; to adalah Umur teoritis pada saat panjang adalah $0 \mathrm{~cm}$.

Persamaan di atas selanjutnya dapat dibawa ke dalam regresi linear sederhana antara $\mathrm{L}_{\mathrm{t}+1}$ dengan fungsi $\mathrm{L}_{\mathrm{t}}$, sehingga diperoleh: 
$\mathrm{L} \infty=\mathrm{a} /(1-\mathrm{b})$,

$\mathrm{K}=-\ln \mathrm{b}$ dan $\mathrm{t}_{0=} \mathrm{t}+\left(\frac{1}{\mathrm{~K}}\right) \ln \frac{(\mathrm{L} \infty-\mathrm{Lt})}{\mathrm{L} \infty}$

Panjang maksimum $\left(\mathrm{L}_{\max }\right)$ ikan selar dapat diketahui dengan mengalikan L $\infty$ dan 0,95, sehingga dengan melakukan variasi nilai $\mathrm{t}$ maka diperoleh umur maksimum $\left(\mathrm{t}_{\max }\right)$ ikan selar.

Mortalitas terdiri dari laju mortalitas total, mortalitas alami dan mortalitas penangkapan. Mortalitas total diperoleh menggunakan metode Length Converted Catch Curve, dengan persamaan (Pauly, 1984):

$\mathrm{Ln} \frac{\mathrm{C}(\mathrm{L} 1+\mathrm{L} 2)}{\Delta \mathrm{t}(\mathrm{L} 1, \mathrm{~L} 2)}=\mathrm{C}-\mathrm{Z} * \mathrm{t}\left(\frac{\mathrm{L} 1+\mathrm{L} 2}{2}\right)$

Keterangan: $\mathrm{L} 1$ adalah $\mathrm{L}_{\mathrm{t}}$, adalah panjang

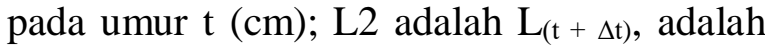
panjang pada umur $\mathrm{t}+\Delta \mathrm{t}(\mathrm{cm}) ; \mathrm{C}$ adalah Frekuensi antara L1 dan L2; $\Delta \mathrm{t}$ adalah Waktu yang diperlukan oleh rataan ikan selar bertumbuh dari panjang L1 ke L2; Z adalah Laju mortalitas total $\left(\mathrm{yr}^{-1}\right)$, diketahui dari $-\mathrm{b}$.

Nilai $M$ dapat dihitung menggunakan rumus empiris Sparre \& Venema (1999) sebagaimana dapat ditulis sebagai berikut:

$\log M=-0,0066-0,279(\log \mathrm{L} \infty)+$ $0,6543(\log K)+0,4634(\log T)$.

Keterangan: $M$ adalah Laju mortalitas alami $\left(\mathrm{yr}^{-1}\right) ; L \infty$ adalah Panjang asimtotik (invinity) (cm); $K$ adalah Koefisien pertumbuhan $\left(\mathrm{yr}^{-1}\right)$; $T$ adalah Suhu rata-rata tahunan $\left({ }^{\circ} \mathrm{C}\right)$.

Laju mortalitas penangkapan dapat diketahui dengan persamaan:

$\mathrm{F}=\mathrm{Z}-\mathrm{M}$

Laju eksploitasi dihitung dengan persamaan menurut Pauly (1980) sebagai berikut:

$\mathrm{E}=\frac{\mathrm{F}}{\mathrm{Z}}$
Keterangan: $E$ adalah Laju eksplotasi $\left(\mathrm{yr}^{-1}\right)$; $Z$ adalah Laju mortalitas total $\left(\mathrm{yr}^{-1}\right) ; F$ adalah Laju mortalitas akibat penangkapan $\left(\mathrm{yr}^{-1}\right)$.

Kondisi stok selanjutnya dianalisis menggunakan metode yield per recruit relatif, dengan persamaan sebagai berikut (Sparre \& Venema, 1999):

$$
\frac{\mathrm{Y} I}{\mathrm{R}}=\mathrm{EU} \mathrm{U}^{\mathrm{M} / \mathrm{K}}\left(1-\frac{3 \mathrm{U}}{1+\mathrm{m}}+\frac{3 \mathrm{U}^{2}}{1+2 \mathrm{~m}}+\frac{\mathrm{U}^{3}}{1+3 \mathrm{~m}}\right),
$$

dimana $U=1-\frac{\mathrm{Lc}}{\mathrm{Loo}} \operatorname{dan} \mathrm{m}=\frac{1-\mathrm{E}}{\mathrm{M} / \mathrm{K}}$

Keterangan: : $\frac{Y r}{R}$ adalah Yield per Recruit relatif; $M$ adalah Laju mortalitas alami $\left(\mathrm{yr}^{-1}\right)$; Lc adalah Length at first capture $(\mathrm{cm}) ; L \infty$ adalah Panjang asimtotik (cm); $K$ adalah Koefisien pertumbuhan $\left(\mathrm{yr}^{-1}\right) ; E$ adalah Laju eksploitasi $\left(\mathrm{yr}^{-1}\right)$

\section{HASIL DAN PEMBAHASAN}

Ikan selar yang dikoleksi di perairan Seram Barat selama penelitian berjumlah 1.890 individu, terkomposisi dari 965 individu betina dan 925 individu jantan atau dengan perbandingan 1: 0,96 . Jumlah tersebut tersebar dari ukuran panjang 13,3$27,2 \mathrm{~cm}$ dengan rataan $19,92 \mathrm{~cm}$. Jumlah koleksi terbesar diperoleh pada bulan Desember $(n=478)$ dan terkecil pada bulan Juli $(n=50)$ dengan rataan tangkapan sebesar $171,89 \mathrm{ind} / \mathrm{bulan}$.

Kelompok ukuran (kohort) ikan selar bervariasi antara 2 dan 3 kohort setiap bulan (Gambar 2). Kohort dengan jumlah individu terbesar ditemukan pada bulan Desember yaitu pada rataan panjang $14,41 \mathrm{~cm}$ dengan jumlah 410 individu, kohort tersebut sekaligus merepresentasi kelompok individu yang paling muda. Kohort dengan jumlah individu terkecil ditemukan pada rataan panjang 18,59 cm dengan jumlah 11 individu dalam distribusi bulan Maret, sedangkan kohort pada rataan panjang $25,87 \mathrm{~cm}$ yang berjumlah 12 individu dan ditemukan pada 
a

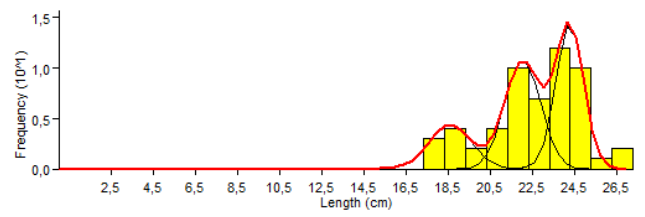

c

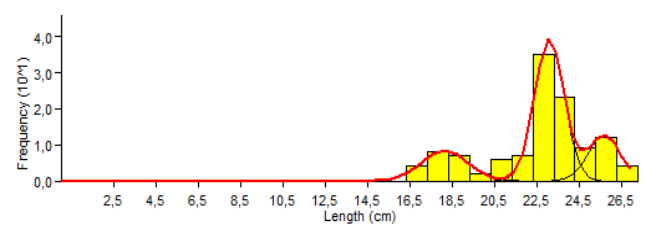

e

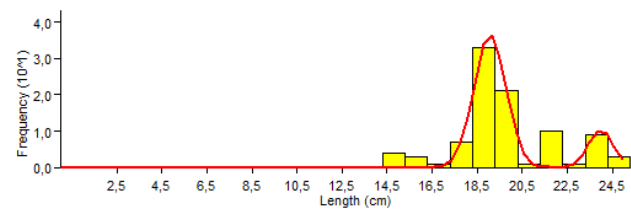

g

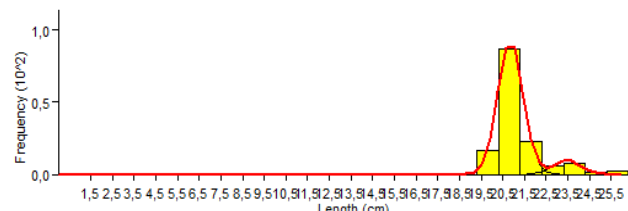

i

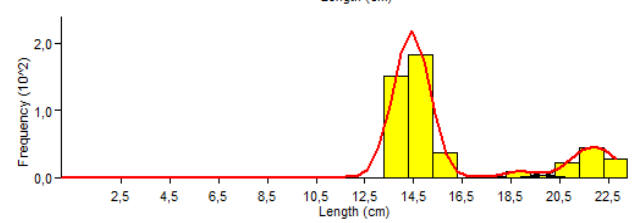

$\mathrm{k}$

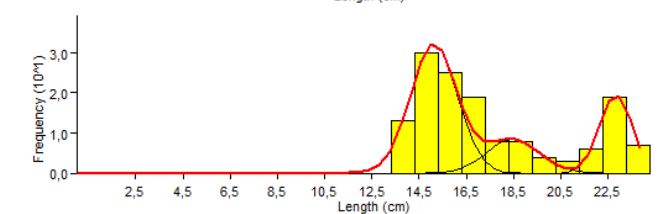

b

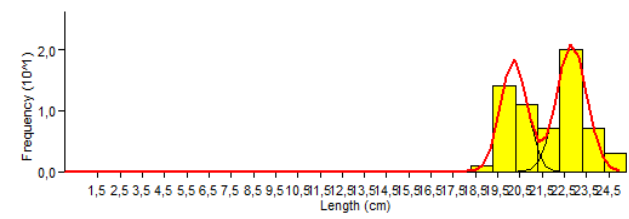

d

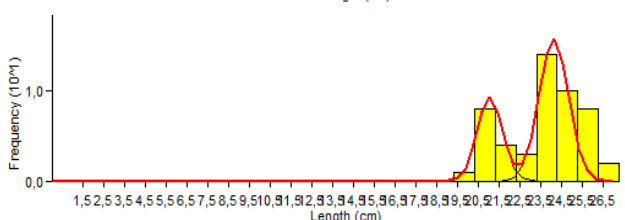

f

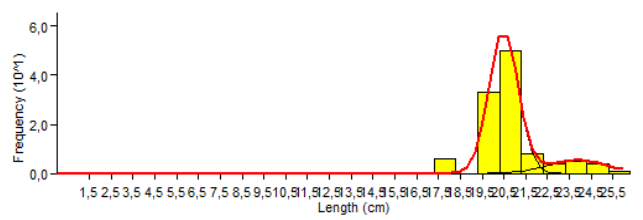

$\mathrm{h}$

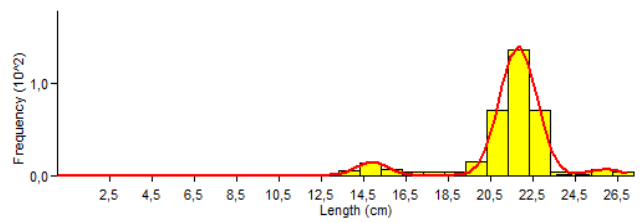

$\mathrm{j}$

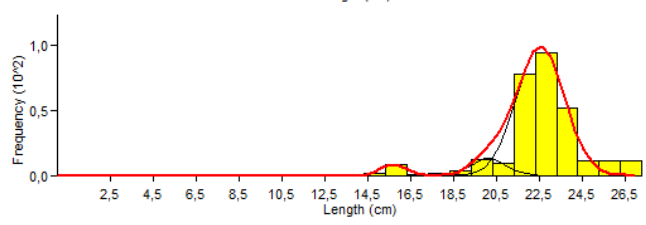

Gambar 2. Distribusi kohort S. crumenophthalmus di perairan Seram Barat menurut bulan: a) Maret 16; b) April; c) Mei; d) Juli; e) Agustus; f) Sepember; g) Oktober; h) November; i) Desember; j) Januari 17; dan k) Februari.

bulan November merupakan kelompok individu tertua.

Kohort hasil analisis bhattacharya terjadi saling tumpang tindih (overlapping) dengan relevansi yang baik. Artinya tumpang tindih antar-kohort tidak terjadi dalam kondisi yang mengganggu sebaran jumlah kohort dan setiap kohort yang berdekatan memiliki hubungan yang baik untuk membentuk kurva normal. Hal ini diterangkan dengan nilai S1 berkisar antara 2,57-8,70, dimana menurut Taylor \& Able (2006), kurva nomal dapat digunakan jika nilai S1 lebih dari 2.

Penelitian Saranga et al. (2018) memperoleh variasi jumlah kohort antara satu hingga dua kohort setiap bulan pada ikan selar di perairan sekitar Bitung. Hal ini menerangkan bahwa variasi kohort dapat terjadi pada spesies yang sama di perairan yang berbeda, meliputi lama/masa tinggal kohort, jumlah dan distribusi kohort. Menururt Mazumder (2015), apabila dikaitkan dengan aktivitas metabolisme organisme perairan, maka perubahan suhu air dapat berpengaruh pada laju kehidupan dan pertumbuhannya. Jika makanan yang tersedia melimpah dan suhu sesuai, maka organisme akan mengalami pertumbuhan yang cepat termasuk perkembangan organisme untuk memijah dan berkembang menjadi kohort baru, sebaliknya jika 
ketersediaan makanan rendah dan suhu kurang mendukung, maka pertumbuhan organisme akan lambat dan proses pembentukan kohort baru akan terganggu. Pertumbuhan ukuran ikan selar untuk membentuk koohort baru melalui pergeseran modus ukuran panjang ikan dari bulan-bulan sebelumnya diperoleh oleh Saranga et al. (2018), yang menerangkan pengaruh parameter lingkungan terhadap pertumbuhan ikan selar.

Tekanan penangkapan juga dapat menjadi faktor pemicu variasi kohort. Jika tekanan penangkapan tinggi, maka distribusi ukuran populasi akan mengalami kemunduran, sehingga distribusi kohort juga dapat mengalami perubahan. Hal ini seperti yang diperoleh Saranga et al. (2018), bahwa terjadi gejala tangkap lebih karena terlalu sedikit ikan tua (kohort terbesar) yang tertangkap.

Rata-rata panjang individu ikan selar yang pertama kali tertangkap (Lc) adalah 19,92 cm, seperti dapat ditampilkan dalam bentuk kurva tangkapan pada Gambar $3 \mathrm{a}$. Nilai yang diperoleh menenunjukkan kondisi perikanan ikan selar berlangsung dengan alat tangkap yang memungkinkan ikan tertangkap pada ukuran rata-rata tersebut.

Sebagai data pembanding, Saranga et al. (2018) memperoleh nilai Lc ikan selar di perairan Bitung sebesar 15,93 $\mathrm{cm}$ dan ukuran ikan pertama kali matang gonad (Lm) 17,63 cm. Semakin tinggi nilai Lc menjelaskan bahwa perikanan setempat semakin selektif. Hal ini sangat penting diperhatikan untuk menjaga ketersediaan stok ikan di perairan, sehingga nilai Lc perlu ditingkatkan dengan meningkatkan selektivitas alat tangkap dan pengaturan pada peserta tangkap.

Pertumbuhan ikan selar di perairan Seram Barat dapat diterangkan dengan persamaan pertumbuhan Von Bertallanfy $\mathrm{Lt}=27,40 \quad\left(1-\mathrm{e}^{-1,55}(\mathrm{t}+0,10) \quad(\right.$ Gambar 3b). Individu ikan selar pada umur awal (antara 0-0,5 tahun) cenderung memiliki pertumbuhan yang cepat hingga mencapai panjang $16,59 \mathrm{~cm}$. Laju pertumbuhan pada umur selanjutnya mulai mengalami perlambatan hingga mencapai umur 1 tahun. Pada umur selanjutnya, individu ikan selar mengalami pertumbuhan yang sangat lambat hingga mencapai panjang maksimum $\left(\mathrm{L}_{\max }\right)$ $26,03 \mathrm{~cm}$ di umur $\left(\mathrm{t}_{\max }\right)$ 1,833 tahun. Panjang teoritis (asimtotik) jika pertumbuhan berlangsung tanpa batas tercapai pada umur 10 tahun dimana individu ikan selar sudah tidak dapat bertumbuh lagi (pertumbuhan $=0 \mathrm{~cm}$ ).

Parameter pertumbuhan ( $\mathrm{L} \infty$ dan $\mathrm{K})$ yang diperoleh berbeda dengan beberapa penelitian sebelumnya. Adeeb et al. (2014) memperoleh nilai L $\infty$ dan $\mathrm{K}$ sebesar 26,54

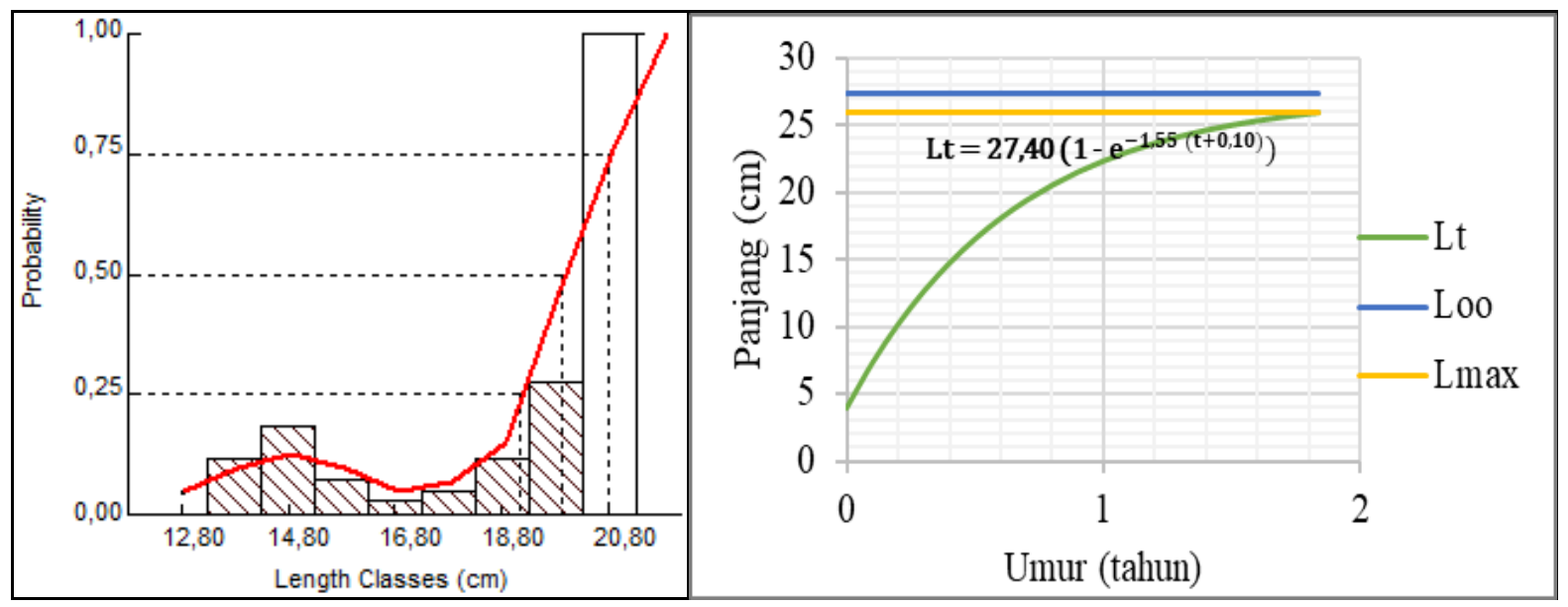

Gambar 3. Kurva tangkapan S. crumenophthalmus di perairan Seram Barat; b) Kurva pertumbuhan $S$. crumenophthalmus di perairan seram Barat. 
cm dan 0,930 $\mathrm{yr}^{-1}$ pada ikan selar di perairan Bangaa Faru Maldives. Khatami et al. (2019) memperoleh L $\infty$ dan K ikan selar di perairan Utara Jawa masing-masing 23,10 $\mathrm{cm}$ dan 0,76 $\mathrm{yr}^{-1}$. Gaerlan et al. (2018) memperoleh $\mathrm{L} \infty$ dan $\mathrm{K}$ pada ikan selar di Teluk Lingayen Filipina, berada pada kisaran 25,29-35,96 cm dan 0,60-1,25 $\mathrm{yr}^{-1}$.

Perbedaan nilai $L_{\infty}$ dan $K$ yang terjadi menunjukkan bahwa spesies yang sama dapat memiliki parameter pertumbuhan yang berbeda tergantung pengaruh lingkungannya. Menurut Espino-Barr et al. (2016), perbedaan nilai dalam analisis parameter pertumbuhan ikan menggunakan model von Bertallanfy disebabkan oleh perbedaan sampel yang dikoleksi, yang ditentukan oleh kondisi lingkungan seperti posisi geografis (garis lintang), suhu perairan, salinitas, dan parameter krusial lain, selain tekanan penangkapan yang berpengaruh pada aspek dinamika populasi ikan. Hal ini berarti semakin tinggi nilai $\mathrm{K}$ (koefisien pertumbuhan) jika lingkungan mendukung maka pertumbuhan ikan selar akan semakin cepat untuk mencapai panjang asimtotiknya $(\mathrm{L} \infty)$.

Laju mortalitas total (Z) ikan selar yang diperoleh 3,66 $\mathrm{yr}^{-1}$ (Gambar 4a). Nilai tersebut merupakan akumulasi dari nilai laju mortalitas alami (M) sebesar 2,51 $\mathrm{yr}^{-1}$ yang diduga pada rata-rata suhu tahunan $29,7{ }^{\circ} \mathrm{C}$, dan laju mortalitas penangkapan (F) sebesar $1,15 \mathrm{yr}^{-1}$.

Tingginya nilai $\mathrm{M}$ dapat dipengaruhi oleh besarnya $\mathrm{L} \infty$ dan $\mathrm{K}$, selain faktor pemangsaan, penyakit, stres pemijahan, kelaparan dan umur tua (Sparre \& Venema, 1999). Laju mortalitas ikan dapat menerangkan kondisi perikanan setempat yang berpengaruh terhadap stok ikan. Jika nilai $M$ lebih besar dari nilai $F$, maka perikanan setempat berada dalam kondisi bebas tekanan penangkapan yang artinya kematian ikan lebih dipengaruhi oleh faktor alamiah, sedangkan jika nilai $\mathrm{M}$ lebih kecil dari nilai F maka kematian ikan lebih banyak diakibatkan oleh aktivitas penangkapan. Kedua jenis mortalitas ini jika memiliki nilai yang sama $(\mathrm{M}=\mathrm{F})$ menunjukkan kondisi perikanan yang berkelanjutan. Berbasis pada hasil yang diperoleh dalam penelitian ini, maka dapat dinyatakan bahwa kondisi perikanan ikan selar masih berada di bawah titik optimum, atau tekanan penangkapan tidak terlalu berpengaruh pada kondisi stok ikan selar.

Hasil penelitian Gearlan et al. (2018) menunjukkan kondisi yang berbeda, dimana laju mortalitas total ikan selar lebih

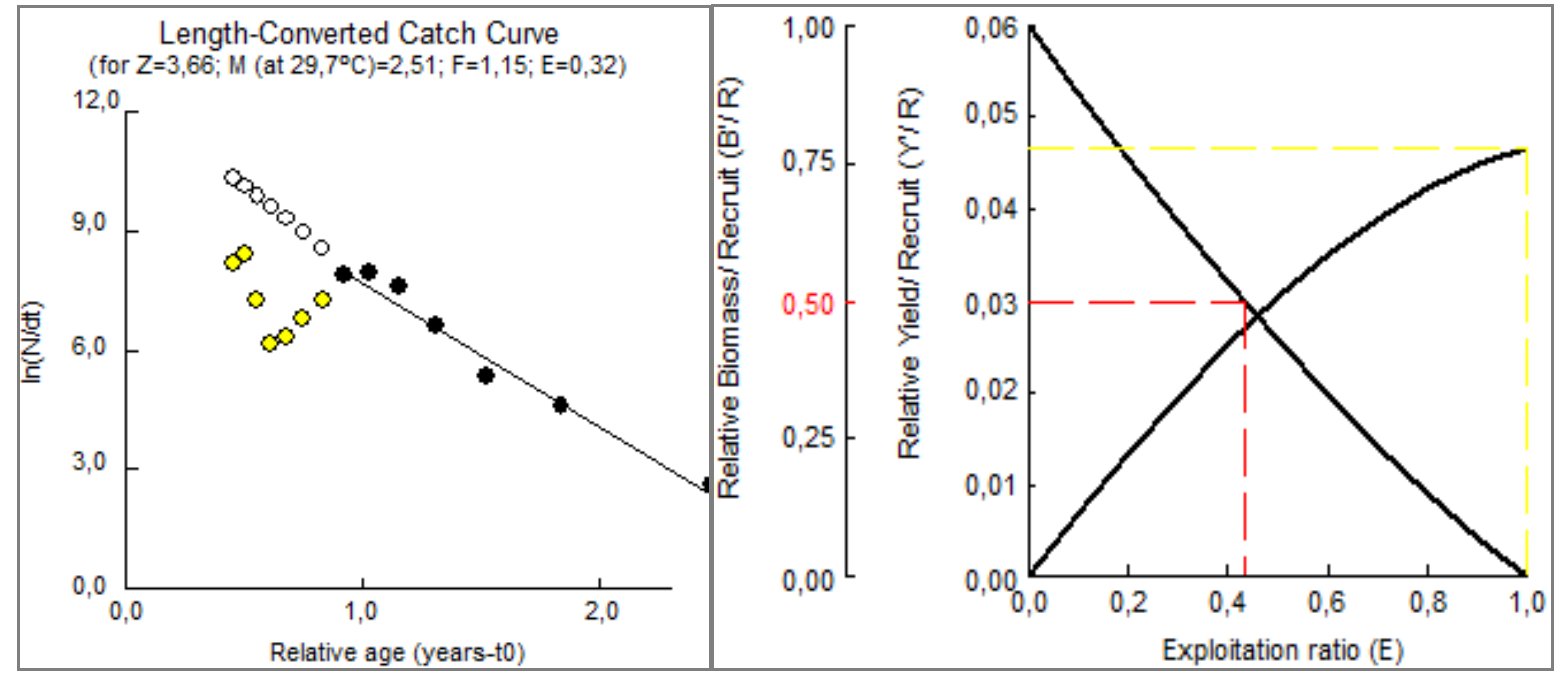

Gambar 4. Length Converted Catch Curve (LCCC); b) Grafik Yield per Recruit (Y'/R) S. crumenophthalmus di perairan Seram Barat. 
dipengaruhi oleh aktivitas penangkapan. Penelitian itu memperoleh nilai $\mathrm{Z}=8,40 \mathrm{yr}^{-1}$ dari akumulasi $\mathrm{M}=1,91 \mathrm{yr}^{-1}$ dan $\mathrm{F}=6,49 \mathrm{yr}^{-}$ 1. Khatami et al. (2019) juga memperoleh kondisi yang sama, laju mortalitas total ikan selar lebih dipengaruhi oleh faktor penangkapan $(2,26)$ dibandingkan faktor alami (1,58). Kondisi yang sama juga diperlihatkan oleh penelitian Adeeb et al. (2014), dimana laju mortalitas penangkapan $\left(2,23 \mathrm{yr}^{-1}\right)$ melebihi laju mortalitas alami $\left(1,78 \mathrm{yr}^{-1}\right)$ untuk menentukan nilai $\mathrm{Z} 4,01 \mathrm{yr}^{-}$ 1. Perbedaan laju mortalitas menunjukkan bahwa nilai $\mathrm{Z}, \mathrm{M}$ dan $\mathrm{F}$ bukan merupakan nilai baku dan akan mengalami fluktuasi seiring fluktuasi tekanan lingkungan yang mempengaruhinya.

Laju mortalitas penangkapan yang rendah menyebabkan laju eksploitasi ikan selar di perairan Seram Barat tergolong rendah. Nilai E ikan selar yang diperoleh sebesar 0,32 $\mathrm{yr}^{-1}$, berbeda dengan hasil penelitian Gearlan et al. (2018) $(\mathrm{E}=23,10)$ dan Khatami (2019) $(E=0,75)$. Menurut Octoriani et al. (2015), jika laju eksploitasi telah melewati nilai 0,5 maka stok suatu sumberdaya ikan dapat dikatakan overfishing. Nilai E ikan selar di perairan Seram Barat yang berada di bawah 0,5 menunjukkan laju eksploitasi masih berada di bawah laju optimum atau stok masih terjauh dari kategori overfishing.

Analisis kondisi stok berbasis dinamika populasi ikan selar menghasilkan nilai $Y^{\prime} / \mathrm{R}$ sebesar 0,03 pada rasio eksploitasi $0,43 \mathrm{yr}^{-1}$, sementara $\mathrm{Y}^{\prime} / \mathrm{R}$ maksimum (MSY relatif) sebesar 0,047 pada rasio eksploitasi 1,00 $\mathrm{yr}^{-1}$ (Gambar 4b). Kondisi tersebut menunjukkan tingkat eksploitasi masih berada di bawah MSY relatif atau tingkat pemanfaatan aktual masih tergolong rendah.

Nilai yang diperoleh di atas berbeda dengan hasil penelitian Adeeb et al. (2014) mengenai $\mathrm{Y}^{\prime} / \mathrm{R}$. Adeeb et al. (2014) memperoleh nilai $\mathrm{Y}^{\prime} / \mathrm{R}$ aktual dan $\mathrm{Y}^{\prime} / \mathrm{R}$ maksimum masing-masing 0,02 dan 0,036 pada ikan selar di perairan Bangaa Faru Maldives. Hal ini disebabkan laju eksploitasi ikan selar di lokasi penelitiannya telah berada dalam kategori overfishing $(\mathrm{E}>0,5)$, sehingga kondisi stok ikan aktual di perairan tergolong kecil.

Gambaran kondisi yield aktual lebih kecil dari yield maksimum memberi informasi kondisi stok ikan selar di perairan Seram Barat yang masih baik sebagai akibat tingkat eksploitasi yang rendah. Melihat kondisi ini, maka terbuka peluang untuk meningkatkan tingkat pemanfaatan sumberdaya perikanan tersebut. Peningkatan jumlah upaya penangkapan dapat dilakukan hingga mencapai FMSY atau tingkat pemafaatan maksimum dimana tidak mengganggu stok lestari namun tetap memberi keuntungan bagi nelayan.

\section{KESIMPULAN}

Kajian kondisi stok yang berbasis aspek dinamika populasi ikan selar di perairan Seram Barat menghasilkan nilai $\mathrm{Y}^{\prime} / \mathrm{R} 0,03$ pada rasio eksploitasi $0,43 \mathrm{yr}^{-1}$ dari $\mathrm{Y}^{\prime} / \mathrm{R}$ maksimum 0,047 pada rasio eksploitasi 1,00 $\mathrm{yr}^{-1}$, yang berarti stok berada dalam keadaan baik sebagai akibat rendahnya laju eksploitasi dibandingkan dengan potensinya. Nilai tersebut diperoleh dari parameter panjang pertama kali tertangkap 19,92 cm, ukuran panjang asimtotik 27,40 $\mathrm{cm}$ dengan koefisien pertumbuhan $1,55 \mathrm{yr}^{-1}$, laju mortalitas total $3,66 \mathrm{yr}^{-1}$, laju mortalitas alami 2,51 $\mathrm{yr}^{-1}$, laju mortalitas penangkapan $1,15 \mathrm{yr}^{-1}$, dan laju eksploitasi 0,32 $\mathrm{yr}^{-1}$. Karakteristik stok ikan selar di perairan Seram Barat disusun oleh 2 hingga 3 kohort setiap bulan.

\section{UCAPAN TERIMA KASIH}

Penulis mengucapkan terima kasih
kepada nelayan bagan perahu yang
membantu dalam pengambilan contoh di
lapangan. Terima kasih juga Penulis
sampaikan kepada Rektor Universitas
Pattimura Ambon yang membantu Penulis
dalam menyelesaikan penelitian ini.




\section{DAFTAR PUSTAKA}

Adeeb, S., N. Fadzly, \& A.S.R. Md. Sah. 2014. Population dynamics of Bigeye Scad, Selar crumenophthalmus in Bangaa Faru, Maldives. J. Mar. Biol. and Oceanogr., 3(3): 1-4. https://doi.org/10.4172/23248661.1000133

Bhattacharya, C.G. 1967. A simple method of resolution, a distribution in to Gaussion Componen. Biometrics, 23(1): 115-135. https://doi.org/102307/2528285

Bunyamin, Wahono H.P., \& O.D Subhakti Hasan. 2016. Analisis Pengelolaan Penangkapan Ikan kembung Lelaki (Rastrelliger kanagurta) secara Berkelanjutan di Perairan Selat Lombok. J. Penyuluhan Perikanan dan Kelautan, 10(3): 181-191. https://doi.org/10.33378/jppik.v10i3 .77

Dimara, O.F., J. Budiman, \& C.F.T. Mandey. 2015. Distribusi tertangkapnya ikan selar pada lembaran jaring soma darape di Rumpon. J. Ilmu dan Teknologi Perikanan Tangkap 2, 1-5. https://doi.org/10.35800/jitpt.2.0.20 15.6964

Espino-Barr, E., M. Gallardo-Cabello, M. Puente-Gómez, \& A. Garcia-Boa. 2016. Growth of the Bigeye Scad Selar crumenophthalmus (Teleostei: Carangidae) in Manzanillo Bay, Mexican Central Pacific. J. Mar. Biol. and Oceanogr., 5(4): 1-7. https://doi.org/10.4172/23248661.1000166

Food and Agriculture Organization (FAO). 1983. Species Identification Sheets. FAO. Rome. 51 p.

Gaerlan, R.S.P., G.A.B. Francis, \& C.R. Felymar. 2018. A review on the status of small pelagic fish resources in the Lingayen Gulf for the Year 2009-2013. J. of Fisheries, 25(1): 1-13.

https://doi.10.31398/tpjf/25.12017C 0001

Gonzales, F.L., S.R. Ganaden, \& F.C. Gayanilo, Jr. 1997. Some population parameters of commercially-important fishes in the Philippines. Fishes Resources Research Division, Bureau of Fisheries and Aquatic Resources. Quenzon city. 114 p.

Kartini, N., M. Boer, \& R. Affandi. 2017. Pola Rekrutmen, Mortalitas, dan Laju Eksploitasi Ikan Lemuru (Amblygaster sirm, Walbaum 1792) di Perairan Selat Sunda. Biospecies, 10(1): 11-16.

https://doi.org/10.22437/biospecies. v10i1.3483

Khatami, M.A., Yonvitner, \& I. Setyobudiyandi. 2019. Tingkat kerentanan sumberdaya ikan pelagis kecil berdasarkan alat tangkap di Perairan Utara Jawa. J. Pengelolaan Perikanan Tropis, 2(1): 19-29. https://doi.org/10.29244/jppt.v2il.25 318

Love, M.S., J.K. Passarelli, C. Okamoto, \& D.W. Diehl. 2016. The Bigeye Scad, Selar crumenophthalmus (Bloch, 1793) (Family Carangidae), New to the California Marine Fauna, with a List to and Keys for All California Carangids. Bull. Southern California Acad. Sci., 114(3): 141-148.

https://scholar.oxy.edu/scas/vol114/ iss $3 / 4$

Mazumder, S.K., Z.C. Cob, A.G. Mazlan, \& S.M. Rahim. 2015. Impact of global climate change on fish growth, digestion and physiological status: developing a hypothesis for cause and effect relationship. J. Water and climate change, 6(2): 200-226. https://doi.org/10.29244/jmf.6.1.6976 
Octoriani, W., A. Fachrudin, \& M. Boer. 2015. Laju eksploitasi sumber daya ikan yang tertangkap pukat cincin di Selat Sunda. J. Marine Fisheries, 6(1): 69-76.

https://doi.org/10.29244/jmf.6.1.6976

Pauly, D. 1984. Fish Population Dynamic in Tropical waters: a manual for use with programmable calculators. Iclarm Studies and Reviews 8. 325 $\mathrm{p}$.

Saranga, R., D. Setyohadi., Z. Arifin., D. Wiadnya., E. Herawati. 2018. Pola pertumbuhan, nisbah kelamin, faktor kondisi, dan struktur ukuran ikan selar, Selar boops (Cuvier, 1833) yang tertangkap di perairan sekitar Bitung. J. Fisheries and marine science, 2(2): 86-94. https://doi.org/10.21776/ub.jfmr.20 18.002.02.5

Sparre, P. \& S.C. Venema. 1999. Introduction to tropical fish stock assessment. Rome. First Edition $306 \mathrm{p}$. https://iwlearn.net/resolveuid/bae3a e95-2b5c-4969-ae69-cc627d4a5c89

Taylor, D.L. \& K.W. Able. 2006. Cohort Dynamics of summer-spawned bluefish as determined by lengthfrequency and otolith microstructure analyses. Transactions of the American Fisheries Society, 135(4): 955-969. https://doi.org/10.1577/T05-109.1

Submitted : 26 April 2021

Reviewed : 12 July 2021

Accepted : 29 July 2021

\section{FIGURE AND TABEL TITLES}

Figure 1. Map of reseacrh location in West Seram.

Figure 2. Distribution of kohort S. crumenophthalmus in west seram waters by month: a) March 16; b) April; c) Mey; d) July; e) August f) September; g) Oktober; h) November; i) December; j) January 17; dan k) February.

Figure 3. a) Catch Curve S. crumenophthalmusin west seram waters; b) Growth Curve S. crumenophthalmus in west seram waters.

Figure 4. a) Length Converted Catch Curve (LCCC); b) Chart of Yield per Recruit (Y'/R) $S$. crumenophthalmus in west seram waters. 